\title{
Assessment of Renewable Energy Projects Using a Decision Support System: A Process to Endorse the Social License to Operate
}

\author{
Sotiris N. Kamenopoulos and Theocharis Tsoutsos
}

\begin{abstract}
The renewable energy projects involve multiple stakeholders; the social acceptance of these projects may convert into a thoughtful risk for the exploitation of renewable energy. Comprehending the process under which a social license to operate may be granted to a renewable energy project is significant. The "GO" or "NO-GO" decision for a renewable energy project is a vital task. In order to illustrate how renewable energy projects can be assessed from the sustainability point of view, two hypothetical scenarios were constructed. These scenarios describe a conceptual renewable energy project evaluated by five imaginary stakeholders under specific criteria and sustainability pillars. The first scenario is a "NO-GO" scenario: the project is not sustainable due to significant environmental, social, economic, technological and geopolitical negative impacts. In this case, the social license to operate will not be endorsed by the stakeholders; important changes are needed before reassessment. The second scenario is a "GO" scenario: the preferences of the stakeholders are such that the project may be considered sustainable and the social license to operate may be endorsed by the stakeholders. The methodology utilized to assess the two hypothetical scenarios for the same renewable energy project is the multi-criteria decision analysis combined with the multi-attribute utility theory. The quantification of assessment results was conducted with the assistance of a state-ofthe-art decision support system ("Acropolis DSS"), which allows decision-makers to evaluate multiple options that offer alternate solutions in "GO-NO-GO" situations.
\end{abstract}

Keywords Renewable energy $\cdot$ Social license to operate $\cdot$ Multi-criteria decision analysis

\footnotetext{
S. N. Kamenopoulos · T. Tsoutsos ( $\square)$

Renewable and Sustainable Energy Lab, School of Environmental Engineering, Technical

University of Crete, Chania, Greece

e-mail: theocharis.tsoutsos@enveng.tuc.gr
} 


$\begin{array}{ll}\text { Abbreviations } \\ \text { DSS } & \text { Decision support system } \\ \text { MAUT } & \text { Multi-attribute utility theory } \\ \text { MCDA } & \text { Multi-criteria decision analysis } \\ \text { NGO } & \text { Nongovernmental organization } \\ \text { REP } & \text { Renewable energy project } \\ \text { RES } & \text { Renewable energy sources } \\ \text { SD } & \text { Sustainable development } \\ \text { SDF } & \text { Sustainable development framework } \\ \text { SLO } & \text { Social license to operate } \\ \text { SMART } & \text { Simple Multi-Attribute Rating Technique } \\ \text { SP } & \text { Sustainable path } \\ \text { UN } & \text { United Nations }\end{array}$

\section{Introduction}

Social license to operate (SLO) as a term was perceived by a Canadian mining executive during the 1990s (Fraser Institute 2012; Prno 2013), and since then it has become an important requirement for the sustainability of several projects. The main scope of this chapter is to present a model for the evaluation of renewable energy projects from the standpoint of social license to operate and social acceptance using a decision support system (DSS). The model used is based on multi-criteria decision analysis (MCDA) and the multi-attribute utility theory (MAUT). Subject DSS incorporates different sustainability indicators as these could be applied to renewable energy projects (REPs). For the purposes of this chapter, the term SLO will refer to the level of acceptance and/or approval by local communities and stakeholders of REPs and their operations (Kamenopoulos et al. 2015a). Compliance with legal regulations may not be the only precondition in the case of REPs; societies may be very doubtful when dealing with a REP, and the lack of faith to policymakers is continuously under reassessment. Stakeholders grant an SLO to a REP when they feel that their values/preferences and those of the REP's company are aligned (Govindan et al. 2014). As a result an SLO is not a permanent treaty, but a dynamic social contract which is contingent on the dynamic changes of multiple stakeholders' preferences; it is dynamic because stakeholders' perceptions can change over time for different reasons (Nelsen 2006); also it could be revoked, and it should never be taken for granted (Kemp et al. 2006). Adaptability is required to manage the complexity associated with the founding and preserving an SLO and sustainable operations (Prno 2013); the absence of the SLO downgrades the possibility of sustainable REP operations; this is how the SLO is straightforward interconnected/ influenced through the current sustainable development practices. As we may see in Fig. 1, sustainable development (SD) practices are the origins of a valid and constant 


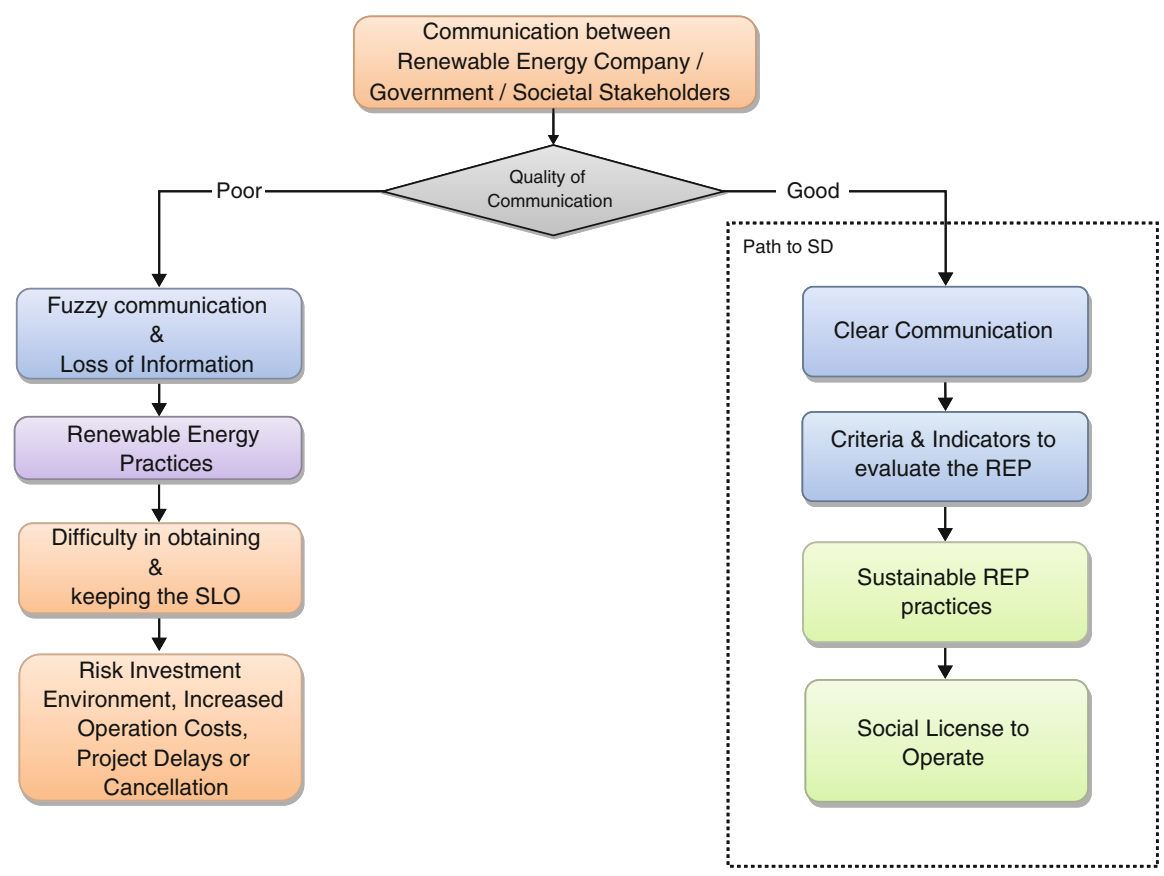

Fig. 1 The modified process that may approve the sustainable exploitation of renewable energy projects and endorse the social license to operate (based on work by Kamenopoulos et al. 2015a, b)

SLO. When a REP is under development, the preferences of involved stakeholders (e.g., local societies, nongovernmental organizations (NGOs), market, government, etc.) are under continuous transformation. Adaptability requires continuous monitoring of stakeholder preferences in every stage of a REP project in order to ensure that the project remains within the sustainable path and the SLO is still valid. Under this continuous "monitoring" process, the decision-makers of a REP may ascertain their decisions on a "GO-NO-GO" frame, adjust policies in accordance with the stakeholders' preferences, and evaluate the project. The notion behind monitoring of stakeholder preferences shall be in such way that preferences are decoded into measurable components within a holistic tool which is flexible and adaptable and continuously supports decision-making.

SLO is straightforward related to the social acceptance of REPs, which is critical for REPs as it could take the form of a risk/uncertainty with severe adverse effects (Lowrance 1976; Kaminaris et al. 2006). These risks may be associated with project delays and/or cancelations due to social turmoil, vandalisms, or increased operational costs (Kamenopoulos and Tsoutsos 2015). These risks may be technological, environmental, social, economic, or geopolitical. As a result, it is very critical to substantiate the reasons why social acceptance comprises a significant risk for which a methodology shall be proposed to address. 
The social acceptance is correlated to the global energy market mix of supply and demand through the securing of renewable energy investments: when local societies grant an SLO to a renewable energy company, the probability of social turmoil due to the project is decreased; as a result, the energy demand is satisfied, and the prices may not be affected. The use of land in the case of REPs may become the stake for competition and create potential turmoil among stakeholders (Granoszewski et al. 2011); it might create disagreements and disputes over access similar to those upon the control and use of natural resources (FAO 2000). The social accountability constituted by SLO requires engagement and relationship-building efforts, which are increasingly prescribed to include "meaningful dialogue" as central (MercerMapstone et al. 2017). Competition over natural resources can lead to, intensify, or sustain violence; conflict over natural resources is often part of, and exacerbates, a larger struggle over political, economic, cultural, or religious issues in the society (US Institute of Peace 2007). Managing natural resource systems usually involves conflicts; behaviors of stakeholders, who might be willing to contribute to improvements and reach a win-win situation, sometimes result in worse conditions for all parties (Madani 2010). Especially in the case of REPs, the use of land became the stake of timeless turmoil in the Greek island of Crete and other areas in Greece; in most cases the competition is related to conflict of interests, i.e., the competitive use of land between renewable energy sources (RES) vise the agricultural/livestock breeding or RES vise the touristic sector and the fear of local societies with regard to potential environmental degradation. RES seem to suffer from the "Not in My Back Yard syndrome (NIMBY)" (Smith and Klick 2007) similarly to the mining sector. No man-made project can completely avoid some impact on the environment so neither can REPs (Tsoutsos et al. 2005). A sustainable solution for the exploitation of RES should at least adjust for environmental protection, resource availability, social welfare, and economic viability of the system (Maria and Tsoutsos 2004). Special procedures should be applied prior to the installation of a renewable energy plant especially in countries with a complicated administrative and legislative system (Tsoutsos et al. 2007, 2015; Kokologos et al. 2014). The remainder of the chapter is organized as follows: The methodological framework is presented in Sect. 2. The evaluated hypothetical scenarios and discussion are presented in Sect. 3; the conclusions are presented in Sect. 4.

\section{Methodological Framework}

Fuzzy communication might create significant negative implications for the acceptance of REPs by stakeholders. If the information is not clearly and transparently shared, the renewable energy firm may be unable to gain an SLO, which refers to the level of acceptance or approval by local communities and stakeholders of renewable energy companies and their operations. This is true regardless of the quality of the renewable energy practices of the firm. The absence of the social license to operate may increase the risks associated with the REP operation. This result is exemplified 
by the left-hand path of Fig. 1. Effective communication, based on SD's criteria and indicators, when coupled with best practices can ultimately lead to the SLO. This is demonstrated on the right side of Fig. 1 (based on work by Kamenopoulos et al. (2015a, b) and adapted to fit the purposes of this chapter).

A sustainability assessment of a REP typically may involve multiple stakeholders with distinct objectives, preferences, and potential conflicts. The "GO" or "NO-GO" decision for a REP project may become a challenging task due to the interrelated multiple quantitative and qualitative parameters with different positive or negative impacts as expressed by the different stakeholders.

In the past, several frameworks, including multi-criteria decision analysis (MCDA) frameworks, were applied in the field of REP evaluation; tools such as the Spanish method and PROMETHEE were exploited (Tsoutsos et al. 2009a, b). In addition, several related developments are present in the literature. Indicatively, to name but a few, we refer to REP evaluations using linguistic MCDM, TOPSIS, MAUT, and others (Doukas and Psarras 2009; Doukas et al. 2009, 2010, 2012; Doukas 2013a, b).

The decision support system (DSS) presented in this chapter is based on a multicriteria decision analysis and on the multi-attribute utility theory (MAUT). The DSS was constructed in the Microsoft Excel ${ }^{\mathrm{TM}} 2013$ environment, and its core is based on criteria and indicators; the DSS may assist decision-makers/stakeholders to better assess the impact of a REP from the sustainability point of view. The proposed DSS shall be integrated into a state-of-the-art sustainable development framework (SDF) (Fig. 2) which was previously developed by Kamenopoulos et al. (2015b).

One of the basic characteristics of the MCDA is the contribution of stakeholders at the decision-making through the negotiation process (trade-offs). In addition, the MCDA integrates unique and personal decision-making practices of individual decision-makers (Kamenopoulos et al. 2018).

The multi-attribute utility theory (MAUT) was created by Keeney and Raiffa (1993). In the MAUT the preferences of the decision-makers are expressed by a utility function which expresses the level of preference that a decision-maker has a set of alternatives; the alternatives are compared under specific criteria (attributes), and every criterion has its own weight (Kamenopoulos et al. 2018). The most common MAUT method is the additive model which is represented by the following equation:

$$
V_{j}=\sum w_{i} p_{i j}
$$

where:

$V_{j}$ is the aggregate score of the $j$ th alternative.

$p_{i j}$ is the score of the $j$ th of the $i$ th criterion.

$w_{i}$ is the weight of $i$ th criterion. 


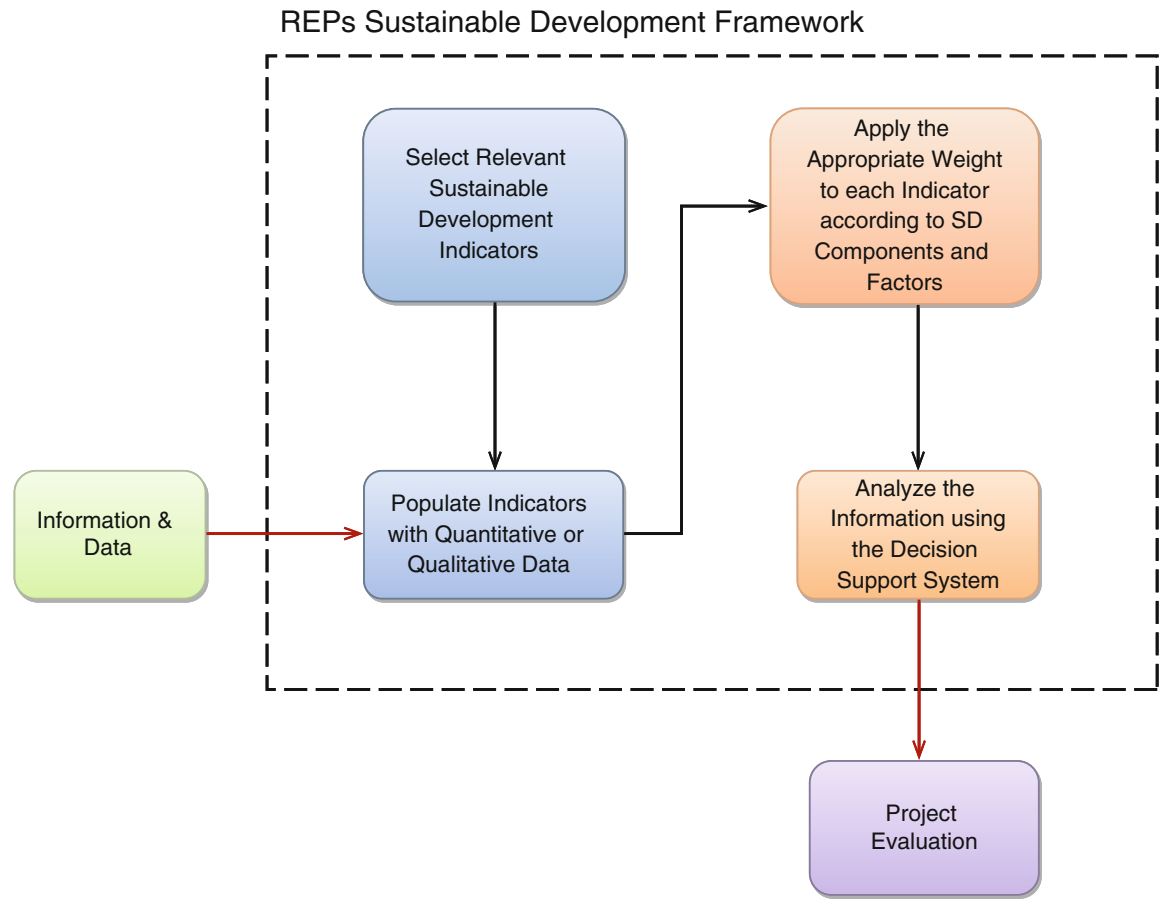

Fig. 2 Modified application of the conceptual framework in the case of renewable energy projects (based on Kamenopoulos et al. 2015b)

A basic constraint of MAUT dictates that the sum of all criteria weights should be equal to one as shown by Eq. (2):

$$
\sum_{i} W_{i}=1
$$

The strength of multi-attribute utility theory (MAUT) lies on the following (Kumar et al. 2017; Kamenopoulos et al. 2018): (a) it accounts for any difference in any criteria, (b) it simultaneously computes preference order for all alternatives, and (c) it dynamically updates value changes due to any impact. The weakness of MAUT lies on the following: it is difficult to have precise input from the decisionmaker, and (b) the outcome of the decision criteria is uncertain. The method which was utilized in order to evaluate the relevant importance of each criterion in terms of weighting factors was the Simple Multi-Attribute Rating Technique (SMART) that was developed by Edwards (1977). The SMART was used in a component part of a hybrid decision support tool for evaluating the sustainability of mining projects, and it was modified for the purposes of this chapter (Kamenopoulos et al. 2018). In that case, the SMART computed the relevant importance of each criterion in two stages (ranking of the criteria and normalization of total score) with the contribution of decision-makers. The modified process allows the formation of a REP's SD index 
Table 1 "GO" or "NO-GO" decision based on the evaluation of "ACROPOLIS" index

\begin{tabular}{l|l|l|l}
\hline ACROPOLIS & Decision & Category—color code & Comments \\
\hline Positive & GO & A-Green & The project is accepted \\
\hline Negative & NO-GO & C-Red & $\begin{array}{l}\text { The project is rejected. Need for critical } \\
\text { changes before evaluated }\end{array}$ \\
\hline Around zero & On hold & B-Orange & $\begin{array}{l}\text { Mitigation measures shall be proposed to } \\
\text { offset impacts. The project has the potential } \\
\text { to be reevaluated }\end{array}$ \\
\hline
\end{tabular}

(Kamenopoulos et al. 2018) that represents the total scoring of decision-maker choices. The following sustainable development index can then be determined (named "ACROPOLIS" index):

$$
\text { “ACROPOLIS" }=100(\mathrm{SPA}-\mathrm{SPB}) /|\mathrm{SPB}|
$$

where:

- The total score of the sustainable path before project start (SPB).

- The total score of the sustainable path after project end (SPA).

A "sustainable path" was defined as "one that allows every future generation the option of being as well off as its predecessors" (US NRC 1994).

The "GO" or "NO-GO" decision for a REP based on the evaluation of the "ACROPOLIS" index is shown in Table 1.

The decision-making process of the proposed DSS is presented in Fig. 3 (based on work by Kamenopoulos et al. (2018) and adapted to fit the purposes of this chapter).

The presented DSS is in a prototype version, and it was designed to include the preferences of five stakeholders, ten quantitative/qualitative indicators, and five sustainable development's pillars (i.e., economy, environment, geopolitics, society, and technology). The model can be modified to incorporate any number of stakeholders, criteria/indicators, or pillars. The proposed model provides the stakeholders with the opportunity for transparent, free decision-making and democratic negotiations, it may quantify/measure the "sustainable path" as this was defined by the US National Research Council, it complies with the UN's SD prerequisites for "...effective citizen participation in decision making and by greater democracy in international decision making..." (UN 1987), and it contributes to gaining and retaining social license to operate. Yet there is no sufficient data yet for testing and it is still in prototype stage (Kamenopoulos et al. 2018).

The process allows several levels of trade-offs between the stakeholders. All criteria/indicators are measured in the same scale for homogeneity reasons; for that reason, a qualitative 5 -Likert scale was selected (1, low; 2 , below average; 3 , average; 4 , above average; 5 , high). The scale and actual values were selected arbitrarily for the purposes of subject chapter. Since there are no actual data available in order to 


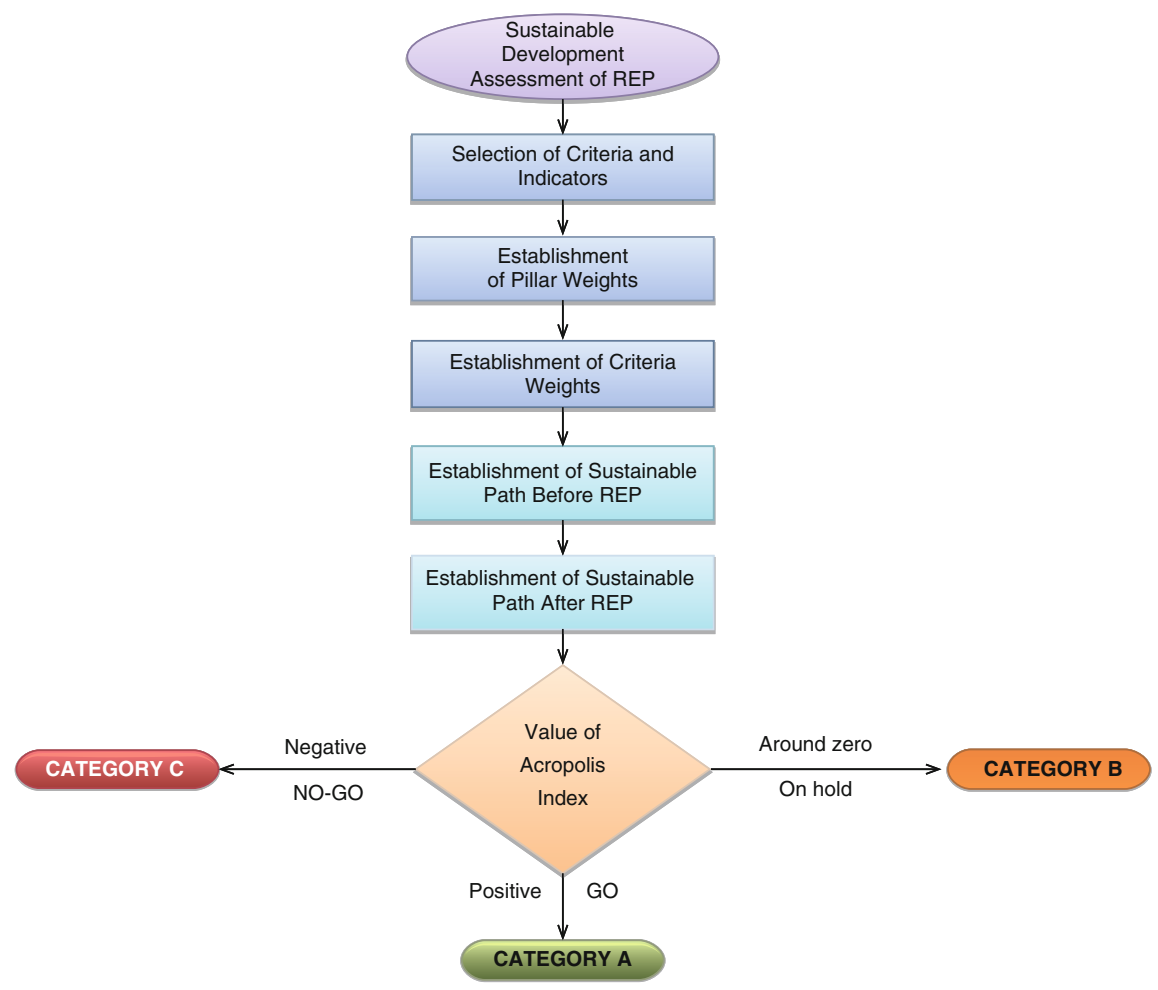

Fig. 3 "GO-NO-GO" decision-making process for REP assessment from the sustainable development point of view (based on work by Kamenopoulos et al. 2018)

test the proposed decision support system, a number of arbitrary assumptions were made (Table 2).

For the purposes of this chapter, ten sustainable development indicators were selected to describe the five pillars of a framework for the evaluation of REPs. The selected indicators and five pillars of sustainability are shown in Table 3.

It should be noted that the proposed model has some advantages as well some disadvantages/limitations that are shown in Table 4 (Kamenopoulos et al. 2018).

\section{The Evaluated Hypothetical Scenarios and Discussion}

Tables 5, 6, 7, and 8 represent the hypothetical "NO-GO" (red color) and "GO" (green color) scenarios. They show the values of pillars' and criteria weights in accordance to five stakeholder ranking preferences and specific values of indicators. They also show the values of sustainable paths (SP), the values of ACROPOLIS index, and the final result in accordance with five stakeholder ranking preferences and specific values of indicators. 
Table 2 Arbitrary assumptions made for the purposes of this paper

\begin{tabular}{l|l}
\hline Assumption & Explanation \\
\hline Number of decision-makers & Five \\
\hline Scenarios & Two scenarios: GO and NO-GO \\
\hline Selection of indicators & Through bibliographic research and authors' choices \\
\hline Sustainability pillars & $\begin{array}{l}\text { Five pillars: environment, economy, society, } \\
\text { technology, geopolitics }\end{array}$ \\
\hline $\begin{array}{l}\text { Ranking of indicators and sustainable } \\
\text { development pillars }\end{array}$ & Selected by the authors \\
\hline Values of indicators & Selected by the authors \\
\hline Criteria/indicators evaluated using & $\begin{array}{l}5 \text {-Likert scale } \\
1=\text { Low } \\
\text { 5-Likert scale }\end{array}$ \\
$\begin{array}{l}2=\text { Below average } \\
3=\text { Average } \\
4=\text { Above average } \\
5=\text { High }\end{array}$ \\
\hline
\end{tabular}

Table 3 Ten sustainable development indicators for SD pillars (environment, economy, society, technology, and geopolitics)

\begin{tabular}{|c|c|}
\hline Pillar & Indicator \\
\hline Environment & $\begin{array}{l}\text { 1. Energy consumption ( } \mathrm{kW} \text { consumed per hectare) } \\
\text { 2. Greenhouse emissions ( } \mathrm{kg} \text { of } \mathrm{CO}_{2} \text { per } \mathrm{kWh} \text { of energy produced) } \\
\text { 3. Waste produced (per } \mathrm{kW} \text { of energy produced) }\end{array}$ \\
\hline Economy & $\begin{array}{l}\text { 4. Average number of people directly employed } \\
\text { 5. Total turnover } \\
\text { 6. Increase of average annual income in the area }\end{array}$ \\
\hline Society & $\begin{array}{l}\text { 7. Number of lost workdays per } 100 \text { full-time equivalent (FTE) employees } \\
\text { 8. Regional life satisfaction/well-being (ranking provided as a subindex of the } \\
\text { OECD Regional Well-Being Index) }\end{array}$ \\
\hline Technology & $\begin{array}{l}\text { 9. Technology index ranking (subindex of Global Creativity Index by Martin } \\
\text { Prosperity Institute, University of Toronto, Canada) }\end{array}$ \\
\hline Geopolitics & 10. Political stability in the country and absence of violence/terrorism ${ }^{c}$ \\
\hline $\begin{array}{l}{ }^{a} \text { The OECD re } \\
\text { that matter in } 1 \\
\text { people, housin } \\
\text { (Accessed } 22 \text { 1 } \\
{ }^{\mathrm{b}} \text { The GCI is a } \\
\text { on the } 3 \text { Ts of } \\
139 \text { nations wo } \\
\text { prosperity. A } \\
\text { April } 4,2017 \text { ) } \\
{ }^{\mathrm{c}} \text { This is an ind } \\
\text { (WGIs). WGIs } \\
\text { by a large num } \\
\text { countries. Thes } \\
\text { organizations, } \\
\text { official views }\end{array}$ & $\begin{array}{l}\text { gional well-being tool provides information about where regions stand on } 11 \text { topics } \\
\text { eople's lives: jobs, income, education, health, civic engagement, safety, access to } \\
\text { g, community, and life satisfaction. At https://www.oecdregionalwellbeing.org/ } \\
\text { Iay 2017) } \\
\text { road-based measure of advanced economic growth and sustainable prosperity based } \\
\text { economic development - talent, technology, and tolerance. It rates and ranks } \\
\text { rldwide on each of these dimensions and on our overall measure of creativity and } \\
\text { http://martinprosperity.org/content/the-global-creativity-index-2015/ (Accessed } \\
\text { icator which is included in the World Bank's Worldwide Governance Indicators } \\
\text { are a research dataset summarizing the views on the quality of governance provided } \\
\text { er of enterprise, citizen, and expert survey respondents in industrial and developing } \\
\text { e data are gathered from a number of survey institutes, think tanks, nongovernmental } \\
\text { international organizations, and private sector firms. The WGIs do not reflect the } \\
\text { f the World Bank, its executive directors, or the countries they represent. At http:// } \\
\text {.org/governance/wgi/\#home (Accessed April 3, 2017) }\end{array}$ \\
\hline
\end{tabular}


Table 4 Advantages and disadvantages of the proposed model

\begin{tabular}{|c|c|}
\hline Advantages & Disadvantages \\
\hline $\begin{array}{l}\text { It provides the stakeholders with the opportunity for } \\
\text { transparent, free decision-making and democratic } \\
\text { negotiations }\end{array}$ & $\begin{array}{l}\text { No sufficient data yet available for } \\
\text { testing/prototype stage }\end{array}$ \\
\hline $\begin{array}{l}\text { It quantifies and measures the US NRC's term of "sus- } \\
\text { tainable path" which was described as “... .one that } \\
\text { allows every future generation the option of being as } \\
\text { well off as its predecessors" }\end{array}$ & $\begin{array}{l}\text { No sufficient data yet available for } \\
\text { testing/prototype stage }\end{array}$ \\
\hline $\begin{array}{l}\text { It complies with the UN's SD prerequisite for } \\
\text { “... .effective citizen participation in decision making } \\
\text { and by greater democracy in international decision } \\
\text { making..." }\end{array}$ & $\begin{array}{l}\text { No sufficient data yet available for } \\
\text { testing/prototype stage }\end{array}$ \\
\hline $\begin{array}{l}\text { It contributes to gaining and retaining "social license to } \\
\text { operate" }\end{array}$ & $\begin{array}{l}\text { No sufficient data yet available for } \\
\text { testing/prototype stage }\end{array}$ \\
\hline $\begin{array}{l}\text { It is a "value"-oriented tool: stakeholders are encour- } \\
\text { aged to incorporate and directly or indirectly express } \\
\text { their "value" on the stake of the project }\end{array}$ & $\begin{array}{l}\text { No sufficient data yet available for } \\
\text { testing/prototype stage }\end{array}$ \\
\hline $\begin{array}{l}\text { It is designed to support all three stages of a project: } \\
\text { before, during, and after project's termination }\end{array}$ & $\begin{array}{l}\text { No sufficient data yet available for } \\
\text { testing/prototype stage }\end{array}$ \\
\hline If modified, it may include any number of SD pillars & $\begin{array}{l}\text { It was built for five SD pillars } \\
\text { Need modifications/prototype stage }\end{array}$ \\
\hline $\begin{array}{l}\text { If modified, it may include an unlimited number of } \\
\text { stakeholders }\end{array}$ & $\begin{array}{l}\text { It was built for five stakeholders } \\
\text { Need modifications/prototype stage }\end{array}$ \\
\hline $\begin{array}{l}\text { If modified, it may include an unlimited number of } \\
\text { indicators }\end{array}$ & $\begin{array}{l}\text { It was built for ten indicators per each } \\
\text { pillar } \\
\text { Need modifications/prototype stage }\end{array}$ \\
\hline If modified, it could also incorporate financial indicators & $\begin{array}{l}\text { Not designed to assess projects from } \\
\text { their financial/economic value }\end{array}$ \\
\hline It incorporates qualitative and quantitative indicators & $\begin{array}{l}\text { No sufficient data yet available for } \\
\text { testing/prototype stage }\end{array}$ \\
\hline $\begin{array}{l}\text { If modified, it may be applicable to any project. Not } \\
\text { necessarily in the mining sector }\end{array}$ & Need modifications/prototype stage \\
\hline $\begin{array}{l}\text { Utilizing parametric analysis the stakeholders may be } \\
\text { provided with additional useful information }\end{array}$ & $\begin{array}{l}\text { No sufficient data yet available/proto- } \\
\text { type stage }\end{array}$ \\
\hline
\end{tabular}

In accordance with the stakeholder's ranking preferences with regard to pillars' weights (Table 5), stakeholders \#1 and \#2 seem to be in favor of the environment and society. The preferences of stakeholders \#3 and \#4 are balanced equally among pillars at the "NO-GO" scenario; stakeholder \#5 seems to be in favor of economy, technology, and geopolitics. Table 6 shows that several trade-offs between stakeholders need to be compromised in order to "move" the project from the "NO-GO" status (red) to "GO" status (green): stakeholders \#1 and \#2 need to compromise and slightly lessen their preferences with regard to the weight of environment. Congruently, stakeholders \#3, \#4, and \#5 need to slightly lessen their preferences with regard to the weights of economy, technology, and geopolitics; respectively, stakeholders \#3, \#4, and \#5 will need to compromise and upsurge their preferences with regard to the weights of environment and society. Equivalent trade-offs need to be 
Table 5 "NO-GO" (red color) and "GO" (green color) hypothetical scenarios: Pillars' weights in accordance with five stakeholder ranking preferences and specific values of indicators

\begin{tabular}{|c|c|c|c|c|c|c|}
\hline Pillars & $\begin{array}{c}\text { Stakeholder } \\
1\end{array}$ & $\begin{array}{c}\text { Stakeholder } \\
2\end{array}$ & $\begin{array}{c}\text { Stakeholder } \\
3\end{array}$ & $\begin{array}{c}\text { Stakeholder } \\
4\end{array}$ & $\begin{array}{c}\text { Stakeholder } \\
5\end{array}$ & $\begin{array}{l}\text { Average } \\
\text { pillar } \\
\text { weight } \\
\text { factors }\end{array}$ \\
\hline Environment & $0.40-0.25$ & $0.40-0.29$ & $0.20-0.29$ & $0.20-0.15$ & $0.06-0.30$ & $0.252-0.254$ \\
\hline Economy & $0.10-0.19$ & $0.10-0.14$ & $0.20-0.12$ & $0.20-0.15$ & $0.29-0.21$ & $0.180-0.163$ \\
\hline Society & $0.30-0.30$ & $0.30-0.36$ & $0.20-0.29$ & $0.20-0.40$ & $0.07-0.21$ & $0.210-0.313$ \\
\hline Technology & $0.10-0.13$ & $0.10-0.14$ & $0.20-0.18$ & $0.20-0.15$ & $0.29-0.14$ & $0.179-0.150$ \\
\hline Geopolitics & $0.10-0.13$ & $0.10-0.07$ & $0.20-0.12$ & $0.20-0.15$ & $0.29-0.14$ & $0.179-0.120$ \\
\hline Sum & $1-1$ & $1-1$ & $1-1$ & $1-1$ & $1-1$ & $1-1$ \\
\hline
\end{tabular}

compromised on the average criteria weights (Table 6): in accordance with the results of Table 5 when the average weights of environmental and societal criteria increase, then the project may move from "NO-GO" status to "GO" status; this result seems to be reasonable since the society general is willing to provide the social license to operate to REPs when only they fulfill environmental and societal standards. The sustainable path (SP) in the case of "NO-GO" scenario seems to be rationally valued (Table 7): if the SP after a REP $(-2.40)$ has a lower value than the SP before the project (1.01), then the society is not willing to grant the social license to operate (i.e., the social acceptance). This is obvious since no society is willing to abate a good social and environmental condition for a worst one. In that case, the value of ACROPOLIS index (Table 8 ) has a negative value (-337.62\%). Correspondingly, the sustainable path (SP) in the case of "GO" scenario seems to be also rationally valued (Table 6): if the SP after a REP (2.90) has a higher value than the SP before the project (1.14), then the society may grant the social license to operate (i.e., the society is willing to accept the project). This could be obvious since society is probably willing to abate a relatively good social and environmental condition for a better one under specific prerequisites; in that case there may be a bargain/trade-off between stakeholders, and if the economic/technological/geopolitical benefits for the society seem to overcome the expected/future social and environmental returns, then the society may grant the social license to operate and accept the project. In that case, the value of ACROPOLIS index (Table 8) has a positive value (154.38\%). Of course, it has to be reminded that each project is unique and the above scenarios are hypothetical.

\section{Conclusions}

In this chapter, a model was demonstrated for the evaluation of REPs from the perspective of SLO using a decision support system and sustainability criteria. The model can assist decision-makers and stakeholders to evaluate a REP and make 
Table 6 "NO-GO" (red color) and "GO" (green color) hypothetical scenarios: Average criteria weights in accordance with five ranking stakeholder preferences and specific values of indicators

\begin{tabular}{|c|c|c|}
\hline Pillar & Criteria & $\begin{array}{l}\text { Average criteria } \\
\text { weight factors }\end{array}$ \\
\hline \multirow[t]{3}{*}{ 1. Environment } & P1C1. Energy consumption & $0.134-0.140$ \\
\hline & P1C2. Gas emissions & $0.134-0.140$ \\
\hline & P1C3. Waste & $0.134-0.140$ \\
\hline \multirow[t]{3}{*}{ 2. Economy } & P2C1. Employment & $0.082-0.060$ \\
\hline & P2C2. Turnover & $0.082-0.060$ \\
\hline & P2C3. Area annual income & $0.082-0.060$ \\
\hline \multirow[t]{2}{*}{ 3. Society } & $\begin{array}{l}\text { P3C1. Number of accidents per } \\
100 \text { FTE employees }\end{array}$ & $0.094-0.150$ \\
\hline & $\begin{array}{l}\text { P3C2. People's happiness \& } \\
\text { well being }\end{array}$ & $0.094-0.150$ \\
\hline 4. Technology & $\begin{array}{l}\text { P4C1. Education and social } \\
\text { programs }\end{array}$ & $0.082-0.060$ \\
\hline 5. Geopolitics & $\begin{array}{l}\text { P5C1. World Bank's political } \\
\text { stability ranking }\end{array}$ & $0.082-0.040$ \\
\hline Sum & & $1-1$ \\
\hline
\end{tabular}

"GO-NO-GO" decisions from the sustainable development's (SD) point of view. The model was based on multi-criteria decision analysis and the multi-attribute utility theory. The model provides the capability to visualize the SD perceptions of citizen participation and greater transparency in a comprehensive mode as recommended in earlier years by the United Nations and quantify the notion of the sustainable path as this was defined by the US National Research Council. The model incorporated criteria and indicators under which two hypothetical scenarios for REPs were evaluated: a "GO" scenario and a "NO-GO" scenario. The two hypothetical scenarios 
Table 7 "NO-GO" (red color) and "GO" (green color) hypothetical scenarios: Values of sustainable paths (SP) in accordance with five stakeholder ranking preferences and specific values of indicators

\begin{tabular}{|c|c|c|}
\hline Sustainable paths & Value NO-GO & $\begin{array}{c}\text { Value } \\
\text { GO }\end{array}$ \\
\hline SP before project (SPB) & 1.01 & 1.14 \\
\hline SP after project (SPA) & -2.40 & 2.90 \\
\hline
\end{tabular}

Table 8 "NO-GO" (red color) and "GO" (green color) hypothetical scenarios: Values of evaluation ACROPOLIS index and final result in accordance with five stakeholder ranking preferences and specific values of indicators

\begin{tabular}{ccc}
\hline $\begin{array}{c}\text { Evaluation } \\
\text { Index }\end{array}$ & Value for NO-GO Scenario & Value for GO Scenario \\
& & \\
\hline ACROPOLIS & $(-2.40-1.01) / 1.01 * 100=-337.62 \%$ & $(2.90-1.14) / 1.14 * 100=154.38 \%$ \\
& $-337.62 \%<<0$ NO-GO & $154.38 \%>>0$ GO \\
\hline
\end{tabular}

involved personal preferences of five decision-makers (stakeholders). Five sustainability pillars were selected: environment, society, economy, technology, and geopolitics. The hypothetical scenarios were subjective and were built under specific assumptions; in addition, it should be noted that each REP has unique characteristics. Indicative results showed that the presented model may provide outcomes that consist of stakeholder's preferences and relatively good judgment.

\section{References}

Doukas, H. (2013a). Modelling of linguistic variables in multi-criteria energy policy support. European Journal of Operational Research, 227(2), 227-238.

Doukas, K. (2013b). Linguistic multicriteria decision-making for energy systems: Building the "RE2S" framework. Wiley Interdisciplinary Reviews Energy and Environment (WIREs), 2(5), 571-585.

Doukas, H., \& Psarras, J. (2009). A linguistic decision support model towards the promotion of renewable energy. Energy Sources, Part B: Economics, Planning, and Policy, 4, 166-178. 
Doukas, H., Karakosta, C., \& Psarras, J. (2009). A linguistic TOPSIS model to evaluate the sustainability of renewable energy options. International Journal of Global Energy Issues, Special Issue "Energy Efficiency, Environmental Performance and Sustainability", 32(1/2), 102-118.

Doukas, H., Karakosta, C., \& Psarras, J. (2010). Computing with words to assess the sustainability of renewable energy options. Expert Systems with Applications, 37(7), 5491-5497.

Doukas, H., Marinakis, V., Karakosta, C., \& Psarras, J. (2012). Promoting renewables in the energy sector of Tajikistan. Renewable Energy, 39, 411-418.

Edwards, W. (1977). How to use multiattribute utility measurement for social decision making. IEEE Transactions on Systems, Man, and Cybernetics, SMC-7, 326-340.

Food and Agricultural Organization - FAO (of United Nations). (2000). Conflict and natural resource management. Accessed September 12, 2017, from http://www.fao.org/forestry/ 21572-0d9d4b43a56ac49880557f4ebaa3534e3.pdf

Fraser Insitute. Miningfacts.org. (2012). What is the social license to operate (SOL)? http://www. miningfacts.org/Communities/What-is-the-social-licence-to-operate/

Govindan, K., Kannan, D., \& Shankar, K. M. (2014). Evaluating the drivers of corporate social responsibility in the mining industry with multi-criteria approach: A multi-stakeholder perspective. Journal of Cleaner Production, 84, 214-232.

Granoszewski, K., Reise, C., Spiller, A., \& Musshoff, O. (2011). The role of land use competition in farmers' engagement in renewable energy production. In VII International Agribusiness PAA-PENSA Conference, "The Multiple Agro Profiles: How to Balance Economy, Environment and Society", November 30-December 2, 2011, Buenos Aires, Argentina.

Kamenopoulos, S. N., \& Tsoutsos, T. (2015). Assessment of the safe operation and maintenance of photovoltaic systems. Energy, 93(2), 1633-1638.

Kamenopoulos, S., Shield, D., \& Agioutantis, Z. (2015a). Sustainable development criteria and indicators for the assessment of rare earth element mining projects, Chapter 6. In I. B. de Lima \& W. L. Filho (Eds.), Rare earths industry: Technological, economic and environmental implications. Amsterdam: Elsevier. isbn:978-0-12-802328-0.

Kamenopoulos, S., Agioutantis, Z., \& Komnitsas, K. (2015b). A framework for sustainable mining of rare earth elements, Chapter 6. In I. B. de Lima \& W. L. Filho (Eds.), Rare earths industry: Technological, economic and environmental implications. Amsterdam: Elsevier. isbn:978-012-802328-0.

Kamenopoulos, S., Agioutantis, Z., \& Komnitsas, K. (2018). A new hybrid decision support tool for evaluating the sustainability of mining projects. International Journal of Mining Science and Technology, 28(2), 259-265.

Kaminaris, S. D., Tsoutsos, T. D., Agoris, D., \& Machias, A. V. (2006). Assessing renewables-toelectricity systems: A fuzzy expert system model. Energy Policy, 34(12), 1357-1366.

Keeney, R. L., \& Raiffa, H. (1993). Decisions with multiple objectives - Preferences and value tradeoffs (p. 569). Cambridge: Cambridge University Press.

Kemp, D., Boele, R., \& Brereton, D. (2006). Community relations management systems in the mineral industry: Combining conventional and stakeholder-driven approaches. International Journal of Sustainable Development, 9(4), 390-403.

Kokologos, D., Tsitoura, I., Kouloumpis, V., \& Tsoutsos, T. (2014). Visual impact assessment method for wind parks a case study in Crete. Land Use Policy, 39, 110-120.

Kumar, A., Sah, B., Singh, A. R., Deng, Y., He, X., Kumar, P., \& Bansal, R. C. (2017). A review of multi-criteria decision making (MCDM) towards sustainable renewable energy development. Renewable and Sustainable Energy Reviews, 69, 596-609.

Lowrance, W. (1976). Of acceptable risk (p. 180). Los Altos: William Kaufmann.

Madani, K. (2010). Game theory and water resources. Journal of Hydrology, 381, 225-238.

Maria, E., \& Tsoutsos, T. (2004). The sustainable management of reneable energy sources installations: Legal aspects of their environmental impact in small Greek islands. Energy Conversion and Management, 45, 631-638.

Mercer-Mapstone, L., Rifkin, W., Moffat, K., \& Louis, W. (2017). Conceptualizing the role of dialogue in social license to operate. Resources Policy, 54, 137-146. 
Nelsen, J. L. (2006). Social license to operate. International Journal of Mining, Reclamation and Environment, 20(3), 161-162.

Prno, J. (2013). An analysis of factors leading to the establishment of a social license to operate in the mining industry. Resources Policy, 38(4), 577-590.

Smith, E.R., Klick, H. 2007. Explaining NIMBY opposition to wind power. Accessed September 12, 2017, from http://www.polsci.ucsb.edu/faculty/smith/wind.pdf

Tsoutsos, T., Frantzeskaki, N., \& Gekas, V. (2005). Environmental impacts from the solar energy technologies. Energy Policy, 33, 289-296.

Tsoutsos, T., Maria, E., \& Mathioudakis, V. (2007). Sustainable siting procedure of small hydroelectric plants: The Greek experience. Energy Policy, 35, 2946-2959.

Tsoutsos, T., Drandaki, M., Frantzeskaki, N., Iosifidis, E., \& Kiosses, I. (2009a). Sustainable energy planning by using multi-criteria analysis application in the island of Crete. Energy Policy, 37, $1587-1600$.

Tsoutsos, T., Tsouchlaraki, A., Tsiropoulos, M., \& Serpetsidakis, M. (2009b). Visual impact evaluation of a winf park in a Greek island. Applied Energy, 86, 546-553.

Tsoutsos, T., Tsitoura, I., Kokologos, D., \& Kalaitzakis, K. (2015). Sustainable siting process in large wind farms. Case study in Crete. Renewable Energy, 75, 474-480.

United Nations (UN). (1987). World Commission on Environment and Development: Report of the World Commission on Environment and Development: Our Common Future. Accessed September 14, 2017, from http://www.un-documents.net/wced-ocf.htm

US Institute of Peace. (2007). Natural resources, conflict and conflict resolution. Accessed September 12, 2017, from https://www.usip.org/sites/default/files/file/08sg.pdf

US National Research Council (NRC). (1994). Assigning economic value to natural resources. Washington, D.C.: National Academy Press. Accessed September 14, 2017, from http://www. nap.edu/catalog/4844.html

Open Access This chapter is licensed under the terms of the Creative Commons Attribution 4.0 International License (http://creativecommons.org/licenses/by/4.0/), which permits use, sharing, adaptation, distribution and reproduction in any medium or format, as long as you give appropriate credit to the original author(s) and the source, provide a link to the Creative Commons license and indicate if changes were made.

The images or other third party material in this chapter are included in the chapter's Creative Commons license, unless indicated otherwise in a credit line to the material. If material is not included in the chapter's Creative Commons license and your intended use is not permitted by statutory regulation or exceeds the permitted use, you will need to obtain permission directly from the copyright holder.

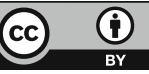

